\title{
Chemical Investigation of Pectoral and Ventral Fins of Fish Cirrhina mrigala At Different Stages of Growth
}

\author{
Babita Agrawal \\ Dept. of Chemistry, B.S.A. College, Mathura \\ babitakanodiya10@gmail.com
}

\begin{abstract}
The present study was undertaken to evaluate the variations in minerals composition, crude fat, crude proteins and component amino acids along with their sequence in the proteins. Calcium and phosphorus form major proportions of minerals while quantity of magnesium being comparatively low. Sodium occurs in traces at all the three stages of growth. Crude fat and crude proteins show a decrease with increasing age. Major quantities of amino acids are serine, hydroxylysis, hydroxyproline, glycine, arginine as these are essentially present in collagen. Amino acids also decrease in their content with increasing age.
\end{abstract}

Keywords: Amino acids, Eriochrome black T, Pectoral fins, Ventral fins, Silica Crucible

\section{INTRODUCTION}

For reason of being organs of locomotion of fishes, fins are of paramount importance and maintain their wave like movements. Mineral and organic analysis of fins at different stages of growth adequately reveal that ageing of fins is association with deposition of mineral in greater proportions which imparts stiffness and hardness to them. Fins of fishes are of two kinds; Median or unpaired fins include dorsal fin anal and caudal fins \& paired fins (pectoral fins, more prominent and large) take a forward position and help to keep aloft the body. The other is pelvic fins or ventral fins, comparatively small and act as additional or secondary elevating planes, when necessity arises. On ageing, the collagen content of fins tend to be organized in the form of coarser fibres. As a result, the tissue of fins become less hydrated, less elastic and therefore, less able to resist mechanical forces (G. B. Talwar, 1980). Ageing brings progressive loss of tissues function along with possible accumulation of diseases including osteoporosis, arthritis, obesity etc. This study deals chemical investigation of Pectoral and Ventral fins of fish Cirrhina mrigala at different stages of growth.

\section{MATERIALS AND METHODS}

First ten fishes of each age group of Cirrhina mrigala were collected. Pectoral and Ventral fins were taken, washed thoroughly in several changes of distilled water, dried in air at room temperature for 36 hours and then ground to a fine powder separately. The crude fat was extracted in a soxhlet extractor using petroleum ether $\left(40^{\circ} \mathrm{C}-60^{\circ} \mathrm{C}\right)$. Nitrogen was determined by Kjeldahl method. Crude protein was determined with the help of total Nitrogen. Amino acids were determined with the help of HPLC. Moisture was determined by keeping $1 \mathrm{~g}$ of the air dried material in an aluminium cup in an electric oven at $100^{\circ} \mathrm{C}$ for 24 hours and then weighing the air dried material in an analytical balance. Ash content was determined by keeping $1 \mathrm{~g}$ of the material in a muffle furnace at $900^{\circ} \mathrm{C}$. Calcium was determined with the help of calcium oxalate. $\mathrm{Mg}$ was determined calorimetrically after removing calcium as calcium sulphate precipitate using the reagent eriochrome black - $\mathrm{T}$. Phosphorus was determined by alkalimetric method. Sodium was precipitated as sodium zinc uranyl acetate and estimated in Eel's colorimeter using green filter. 
International Journal of Research in Advent Technology, Vol.7, No.2, February 2019 E-ISSN: 2321-9637

Available online at www.ijrat.org

Table 1: Mineral composition of Pectoral and Ventral fins of Fish Cirrhina mrigala at three different stages of growth

(Value are expressed as $\mathrm{g} / 100 \mathrm{~g}$ of the dry material)

\begin{tabular}{|c|c|c|c|c|c|c|c|c|c|c|c|c|c|c|c|}
\hline \multirow{2}{*}{$\begin{array}{c}\text { Sta } \\
\text { ges } \\
\text { of } \\
\text { Gr } \\
\text { ow } \\
\text { th }\end{array}$} & \multicolumn{3}{|c|}{$\begin{array}{l}\text { Average age of } 10 \\
\text { fish }\end{array}$} & \multicolumn{2}{|c|}{ Moisture } & \multicolumn{2}{|c|}{ Ash } & \multicolumn{3}{|c|}{ Mineral Values } & \multicolumn{3}{|c|}{ Mineral Oxides Values } & \multicolumn{2}{|c|}{$\begin{array}{c}\text { Ash } \\
\text { Unaccounted } \\
\text { for }\end{array}$} \\
\hline & $\begin{array}{l}\text { Leng } \\
\text { th } \\
(\mathrm{cm})\end{array}$ & $\begin{array}{c}\text { Gir } \\
\text { th } \\
\text { (c } \\
\text { m) }\end{array}$ & $\begin{array}{c}\text { Wei } \\
\text { ght } \\
\text { (g) }\end{array}$ & $\begin{array}{l}\text { Pect } \\
\text { oral } \\
\text { Fins }\end{array}$ & $\begin{array}{c}\text { Vent } \\
\text { ral } \\
\text { Fins }\end{array}$ & $\begin{array}{l}\text { Pect } \\
\text { oral } \\
\text { Fins }\end{array}$ & $\begin{array}{c}\text { Vent } \\
\text { ral } \\
\text { Fins }\end{array}$ & & $\begin{array}{l}\text { Pect } \\
\text { oral } \\
\text { Fins }\end{array}$ & $\begin{array}{c}\text { Vent } \\
\text { ral } \\
\text { Fins }\end{array}$ & & $\begin{array}{l}\text { Pector } \\
\text { al Fins }\end{array}$ & $\begin{array}{l}\text { Ventra } \\
\text { l Fins }\end{array}$ & $\begin{array}{l}\text { Pect } \\
\text { oral } \\
\text { Fins }\end{array}$ & $\begin{array}{c}\text { Ventr } \\
\text { al } \\
\text { Fins }\end{array}$ \\
\hline \multirow[t]{2}{*}{ I } & \multirow[t]{2}{*}{30} & \multirow[t]{2}{*}{16} & \multirow[t]{2}{*}{2700} & \multirow[t]{2}{*}{11.30} & \multirow[t]{2}{*}{11.50} & \multirow[t]{2}{*}{53.75} & \multirow[t]{2}{*}{53.29} & \multirow[t]{2}{*}{$\begin{array}{c}\mathrm{Ca} \\
\mathrm{Mg} \\
\mathrm{Na} \\
\mathrm{P} \\
\mathrm{F}_{2}\end{array}$} & \multirow[t]{2}{*}{$\begin{array}{c}20.78 \\
0.36 \\
0.005 \\
10.49 \\
0.025\end{array}$} & \multirow[t]{2}{*}{$\begin{array}{c}20.59 \\
0.36 \\
0.005 \\
10.40 \\
0.023\end{array}$} & $\begin{array}{l}\mathrm{CaO} \\
\mathrm{MgO} \\
\mathrm{Na}_{2} \mathrm{O} \\
\mathrm{P}_{2} \mathrm{O}_{5}\end{array}$ & $\begin{array}{c}29.09 \\
0.6 \\
0.0067 \\
24.02\end{array}$ & $\begin{array}{c}28.83 \\
0.6 \\
0.0067 \\
23.82\end{array}$ & \multirow[t]{2}{*}{$\begin{array}{l}0.033 \\
3\end{array}$} & \multirow[t]{2}{*}{0.0333} \\
\hline & & & & & & & & & & & Total & 53.7167 & 53.2567 & & \\
\hline \multirow[t]{2}{*}{ II } & \multirow[t]{2}{*}{61} & \multirow[t]{2}{*}{30} & \multirow[t]{2}{*}{5355} & \multirow[t]{2}{*}{11.28} & \multirow[t]{2}{*}{11.48} & \multirow[t]{2}{*}{67.01} & \multirow[t]{2}{*}{68.39} & \multirow[t]{2}{*}{$\begin{array}{c}\mathrm{Ca} \\
\mathrm{Mg} \\
\mathrm{Na} \\
\mathrm{P} \\
\mathrm{F}_{2}\end{array}$} & \multirow[t]{2}{*}{$\begin{array}{c}25.43 \\
0.44 \\
0.008 \\
13.38 \\
0.033\end{array}$} & \multirow[t]{2}{*}{$\begin{array}{c}25.20 \\
0.43 \\
0.006 \\
13.26 \\
0.029\end{array}$} & $\begin{array}{l}\mathrm{CaO} \\
\mathrm{MgO} \\
\mathrm{Na}_{2} \mathrm{O} \\
\mathrm{P}_{2} \mathrm{O}_{5}\end{array}$ & $\begin{array}{c}35.60 \\
0.73 \\
0.0081 \\
30.64\end{array}$ & $\begin{array}{c}35.28 \\
0.72 \\
0.0081 \\
30.37\end{array}$ & \multirow[t]{2}{*}{$\begin{array}{l}0.031 \\
9\end{array}$} & \multirow[t]{2}{*}{0.0119} \\
\hline & & & & & & & & & & & Total & 66.9781 & 66.3781 & & \\
\hline \multirow[t]{2}{*}{ III } & \multirow[t]{2}{*}{89} & \multirow[t]{2}{*}{35} & \multirow[t]{2}{*}{7950} & 11.03 & 11.23 & 73.03 & 72.41 & $\begin{array}{c}\mathrm{Ca} \\
\mathrm{Mg} \\
\mathrm{Na} \\
\mathrm{P} \\
\mathrm{F}_{2}\end{array}$ & $\begin{array}{c}28.57 \\
0.54 \\
0.005 \\
14.00 \\
0.034\end{array}$ & $\begin{array}{c}28.33 \\
0.55 \\
0.004 \\
13.89 \\
0.032\end{array}$ & $\begin{array}{l}\mathrm{CaO} \\
\mathrm{MgO} \\
\mathrm{Na}_{2} \mathrm{O} \\
\mathrm{P}_{2} \mathrm{O}_{5}\end{array}$ & $\begin{array}{c}40.00 \\
0.9 \\
0.0067 \\
32.06\end{array}$ & $\begin{array}{c}39.66 \\
0.9 \\
0.0067 \\
31.81\end{array}$ & $\begin{array}{l}0.063 \\
3\end{array}$ & 0.0333 \\
\hline & & & & & & & & & & & Total & 72.9667 & 72.3767 & & \\
\hline
\end{tabular}

Table 2: Crude fat, Total Nitrogen and Crude protein contents of the Pectoral and Ventral Fins of Fish Cirrhina mrigala at three different stages of growth. (Values are expressed as $\mathrm{g} / 100 \mathrm{~g}$ of the dry material)

\begin{tabular}{|c|c|c|c|c|c|c|c|c|c|}
\hline $\begin{array}{c}\text { Stages } \\
\text { of } \\
\text { Growth }\end{array}$ & \multicolumn{2}{|c|}{ Average age of 10 fish } & \multicolumn{3}{|c|}{ Pectoral Fins } & \multicolumn{3}{c|}{ Ventral Fins } \\
\cline { 2 - 10 } & $\begin{array}{c}\text { Length } \\
(\mathbf{c m})\end{array}$ & $\begin{array}{c}\text { Girth } \\
(\mathbf{c m})\end{array}$ & $\begin{array}{c}\text { Weight } \\
\mathbf{( g )}\end{array}$ & $\begin{array}{c}\text { Crude } \\
\mathbf{f a t}\end{array}$ & $\begin{array}{c}\text { Total } \\
\mathbf{N}\end{array}$ & $\begin{array}{c}\text { Crude Protein } \\
\mathbf{( N \times 6 . 2 5})\end{array}$ & $\begin{array}{c}\text { Crude } \\
\text { fat }\end{array}$ & $\begin{array}{c}\text { Total } \\
\mathbf{N}\end{array}$ & $\begin{array}{c}\text { Crude } \\
\text { Protein (N } \mathbf{x} \\
\mathbf{6 . 2 5})\end{array}$ \\
\hline I & 30 & 16 & 2700 & 0.67 & 7.29 & 45.55 & 0.68 & 7.36 & 46.00 \\
\hline II & 61 & 30 & 5355 & 0.53 & 5019 & 32.42 & 0.58 & 5028 & 33.00 \\
\hline III & 89 & 35 & 7950 & 0.44 & 4024 & 26.49 & 0.46 & 4.33 & 27.09 \\
\hline
\end{tabular}

$\underline{\text { Total of Crude Protein, Crude Fat, Fluorine and Ash }}$

\begin{tabular}{lll} 
Pectoral Fin & Stage I & $45.55+0.67+53.75+0.025=\mathbf{9 9 . 9 9}$ \\
& Stage II & $32.42+0.53+67.01+0.031=\mathbf{9 9 . 9 9}$ \\
& Stage III & $26.49+0.44+73.03+0.034=\mathbf{9 9 . 9 9}$ \\
Ventral Fin & & \\
\hline \multirow{4}{*}{ Stage I } & $46.00+0.68+53.29+0.023=\mathbf{9 9 . 9 9}$ \\
& Stage II & $33.00+0.58+66.33+0.029=\mathbf{1 0 0 . 0 0}$ \\
& Stage III & $27.09+0.46+72.41+0.032=\mathbf{9 9 . 9 9}$
\end{tabular}


Table 3: Amino acid composition of Pectoral and Ventral fins of Fish Cirrhina mrigala at three different stages of growth. (Values are expressed as $\mathrm{g} / 100 \mathrm{~g}$ of the dry material)

\begin{tabular}{|c|c|c|c|c|c|c|c|}
\hline \multirow{2}{*}{$\begin{array}{c}\text { S. } \\
\text { No. }\end{array}$} & \multirow{2}{*}{ Amino Acid } & \multicolumn{3}{|c|}{ Pectoral Fins } & \multicolumn{3}{c|}{ Ventral Fins } \\
\cline { 3 - 8 } & & Stage I & Stage II & Stage III & Stage I & Stage II & Stage III \\
\hline 1. & Alanine & 0.53 & 0.41 & 0.47 & 0.54 & 0.42 & 0.48 \\
\hline 2. & Arginine & 1.91 & 1.33 & 1.05 & 1.94 & 1.35 & 1.07 \\
\hline 3. & Aspartic Acid & 0.30 & 0.27 & 0.25 & 0.30 & 0.28 & 0.26 \\
\hline 4. & Cystine & 1.02 & 1.08 & 0.94 & 1.03 & 1.11 & 0.96 \\
\hline 5. & Glutamic Acid & 1.13 & 0.76 & 0.52 & 1.14 & 0.77 & 0.53 \\
\hline 6. & Glycine & 2.43 & 2.28 & 1.80 & 2.45 & 2.32 & 1.83 \\
\hline 7. & Histidine & 0.73 & 0.52 & 0.45 & 0.74 & 0.53 & 0.46 \\
\hline 8. & Isoleucine & 0.59 & 0.47 & 0.39 & 0.60 & 0.48 & 0.40 \\
\hline 9. & Leucine & 0.67 & 0.62 & 0.43 & 0.68 & 0.63 & 0.44 \\
\hline 10. & Lysine & 0.51 & 0.39 & 0.21 & 0.51 & 0.40 & 0.22 \\
\hline 11. & Methionine & 0.41 & 0.31 & 0.24 & 0.41 & 0.33 & 0.25 \\
\hline 12. & Phenyl alanine & 0.55 & 0.47 & 0.48 & 0.56 & 0.48 & 0.49 \\
\hline 13. & Proline & 0.20 & 0.15 & 0.13 & 0.16 & 0.14 & 0.13 \\
\hline 14. & Serine* & 4.08 & 2.18 & 1.69 & 4.12 & 2.22 & 1.72 \\
\hline 15. & Threonine* & 0.76 & 1.22 & 0.96 & 0.77 & 1.24 & 0.98 \\
\hline 16. & Tryptophan & 0.54 & 0.34 & 0.24 & 0.55 & 0.35 & 0.25 \\
\hline 17. & Tyrosine & 0.32 & 0.27 & 0.25 & 0.33 & 0.28 & 0.26 \\
\hline 18. & Valine & 0.45 & 0.33 & 0.29 & 0.46 & 0.34 & 0.30 \\
\hline 19. & Hydroxy proline & 3.35 & 1.74 & 1.40 & 3.38 & 1.77 & 1.43 \\
\hline 20. & Cysteine & 0.49 & 0.35 & 0.28 & 0.49 & 0.36 & 0.29 \\
\hline 21. & Hydroxylysine & 3.54 & 2.28 & 1.68 & 3.57 & 2.32 & 1.71 \\
\hline & Total & $\mathbf{2 4 . 5 1}$ & $\mathbf{1 7 . 7 7}$ & $\mathbf{1 4 . 1 5}$ & $\mathbf{2 4 . 7 3}$ & $\mathbf{1 8 . 1 2}$ & $\mathbf{1 4 . 4 6}$ \\
\hline
\end{tabular}

$\mathrm{N}$ - Terminal residue not determined.

- $\mathrm{CONH}_{2}$ group not determined.

* - Corrected for the loss during hydrolysis.

\section{RESULTS AND DISCUSSION}

The mineral analysis of Pectoral fins and Ventral fins of fish Cirrhina mrigala shows that moisture contents of both the fins decrease from Stage I to Stage III of ageing. The moisture contents follow the order - Pectoral Fin < Ventral Fin. Ash contents of both the fins of fish exhibit an increase from Stage I to Stage III of ageing. The total ash contents of both the fins follow the order opposite to that of moisture content i.e., Pectoral Fin > Ventral Fin. Calcium content of Pectoral fin is maximum, calcium content increases from Stage I to Stage III of growth in both the fins. Phosphorus is also the major constituent of both the fins of fish. Sodium occurs in traces in both the fins. Amount of magnesium is minute at all the stages.

Table 2 shows that the value of crude fat, total nitrogen and crude protein decreases from Stage I to Stage III of ageing.

Table 3 indicates that at all the three stages of growth, Pectoral and Ventral fins both contain twenty one amino acids of the collagen group. Total amino acid content decreases from Stage I to Stage III in both the fins. Serine occurs in the maximum quantity at Stage I whereas at Stage II glycine and hydroxylsine are equal \& maximum. Amino acids present in appreciable amount are arginine, Cysteine, glutamic acid, glycine, serine, hydroxyl proline and hydroxylysine. Total value of amino acids of Pectoral fins at Stages I, II and III are 24.51, 17.77 and 14.15 respectively. Total values of amino acids of Ventral fins at Stages I, II and III are 24.75, 18.12 and 14.46 respectively.

\section{CONCLUSION}

Results of the minerals and organic constituents of both fins (Pectoral and Ventral) are reported. Ash content increases with ageing while moisture content decreases. All minerals are found in increasing order. The study shows that crude fat and crude protein decrease in both the fins as a result of growth. Total amino acid content decreases from Stage I to Stage III. However, all the ten essential amino acids are invariably present in both the fins. It reveals that ageing of both the fins is associated with deposition of minerals in greater proportions which imparts stiffness and hardness to them. As well amino acids decreases with increasing age. 


\section{REFERENCES}

[1] Albert, L. Lehninger (1987), Principles of bioChemistry P-160.

[2] Barnard, J. A. R. Chayen (1965), Modern methods of Chemical Analysis, Mc Graw hill Publishing company Ltd London, p -215.

[3] Buerger, L. and Gies, W. J. (1901), Am. J. Physiol 6:219.

[4] Cameron, A.T. (1946), A Text Book of biochemistry for students of medicine and science p210.

[5] Chibnall, A. C. (1942), Proc. Roy. Soc. B 131-136.

[6] Cumming and Kay (1956), Quantitative chemical analysis revised by Robert Alaxander, Chalmers, Oliver and Boyd. Edinburgh. London P 111-112, 124-125, 332-334.

[7] Deshmukh, K. and Nimni, M. E. (1948), Chemical changes associated with ageing of collagen in vivo and vitro. J. Biochem. 397.

[8] Hiroyuki Hanai, Makoto Ishida, C. Tony Liang and Bertram Sacktor (1986), Parathyroid Hormone increases Sodium/Calcium exchange activity in renal cells and the blunting of the response in ageing. The Journal of Biological chemistry. Vol. 261, No. 12, Issue of April 25, pp-5419-5425, 1986. Printed in U.S.A

[9] Lansing, A.I., Roberts, E., Ramasarma, G. B., Rosenthal, T. B. and Alese, M. (1951), Changes with age in amino acid composition of arterial elastin Proc. Soc. exper. Biol. And Ned. 76:714717.

[10] Patricia C. Brown and Dr. R consden (1958), Variation with age of Shrinkage temp. of collagen (human) Nature 1, 349.

[11]R. C. Saraswat and R. K. Garg (1974), Studies on the mineral constituents of fins of wallago attu (Bloch and Schneider) at different stages of growth. Indian J. animal. Research 8(1) 36-38.

[12] Robin Holliday (1988), Genes, Proteins and cellular ageing. Indian Journal of Experimental Biology, Vol. 26, April 1988, p-327.

[13] Saraswat R.C. and Newton Ram (1972), Organic composition of fins of fish wallago attu (Bloch \& Schncidere) at different stages of growth. Indian Journal of experimental Biology, Vol. 10, No. 3 pp. 243-244.

[14] Thakur, M. K. (1984), Age related changes in the structure and function of chromatin: A review. Mech. Ageing Dev. 27, pp-263-286. 